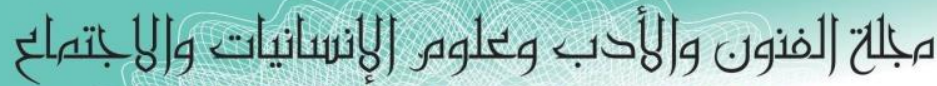

Journal of Arts, Literature, Humanities and Social Sciences

ISSN online: 2414 - 3383

ISSN print: 2616 - 3810

العدد (41) آب - أغسطس 2019

\title{
The Effect of Using Tiered Activities Strategy upon the Achievement of History of the Arab Islamic Civilization Subject and Cognitive Motive among Fourth Literary Female Students
}

\author{
Assistant Professor Dr. Huda Fadhel Hussein \\ Department of History \\ College of Arts -Al-Iraqia University \\ Email: huda.fadel1982@gmail.com
}

\begin{abstract}
The research paper aims to identify the effect of using tiered activities upon the achievement and cognitive motive among fourth -grade literary stream female students. The researcher has used the experimental design of partial control and posttest .She has chosen the auditorium (A) to represent the experimental group that has been taught according to the tiered activities strategy and the auditorium (B) to represent the control group that has been taught to the traditional method. The number of the female students has amounted to (60) by (30) female students in each group. The equivalence of female students of the two groups has been applied in the following variables: age test, history subject mid-term test score and parents' academic achievement. The researcher has conducted two tools including achievement test, the cognitive motive scale .The validity and reliability of the two tools have been verified by using T-test to process data .Results show the excellence of the experimental group that has been taught according to the tiered activities strategy in achieving of history of the Arab Islamic civilization and the cognitive motive scale among fourth female students of literary stream .
\end{abstract}




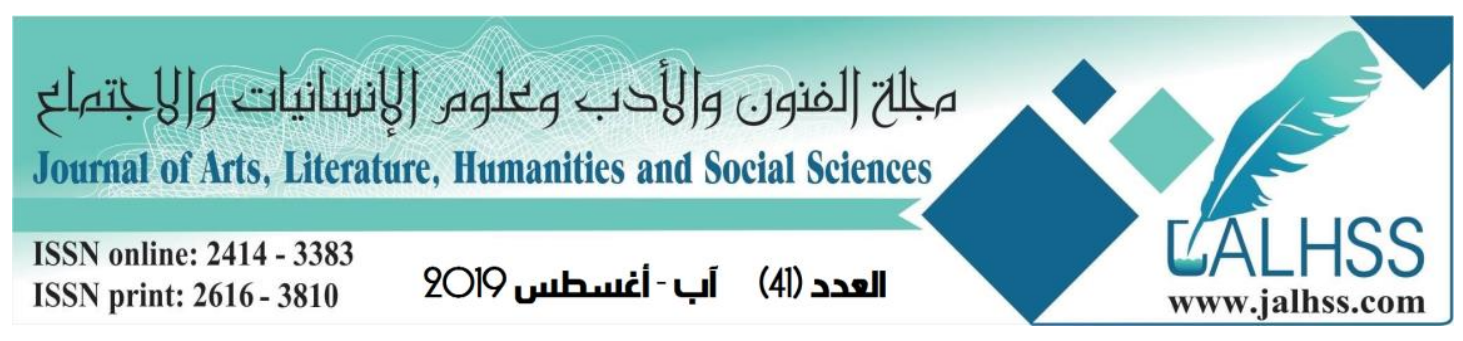

\section{Statement of the Problem}

The researcher, through her survey and review of previous researches, educational studies and references that deal with teaching the history subject together with its methodology, has found out that a great interest in achieving this subject as well as developing the cognitive abilities and motives of students in learning this subject, far from what teachers have followed teaching methods that depend on memorization, and indoctrination .Accordingly, students are subject to forget what they have already learnt without understanding and perception of subjects correlation. This led that they will never develop cognitive motive towards learning history subject. Nevertheless , many studies and research papers relating to social sciences teaching methods including history have confirmed that students found this subject very difficult .As a result, they didn't appeal to study it .The reason behind this fact is that the traditional methods employed in teaching history and the method of presenting information as well as the amount of information that students should know and memorize regardless of other aspects (Abdulaziz 1995 ,p:101-116)(Al-Gamal ,1997:p.2)

Many other studies have pointed out that there is a decline in the level of acquiring historical concepts because they came to deep and accurate understanding .(Al-Teti ,1983)(Kresti,1997 pp:115-116) (Al-Shawan:1999:p.137) (Al-Makhlaqi and Hamad 2001:12)

To achieve the optimal objective of teaching history subject matter , the researcher attempts to find out new methods or strategies of teaching made the roles of students very positive in learning information and they will be active participants in the process of learning as well as promoting their cognitive motives in learning process.

One of the most important strategies is tiered activities strategy which is based on diversity of teaching through designing tiered activities in that each student starts to do his or her suitable cognitive skillful activity .(Kojak et al 2008,131-132)

The problem is based on the following research questions:

1.What is the impact of tiered activities strategy in achieving of history of the Arab Islamic civilization subject among fourth grade female students.

2.What is the impact of tiered activities strategy in the cognitive motive among fourth grade female students.

\section{Significance of the Study}

History is not the study of the past but the study of the present traces of the past. For the purpose of clarifying and explaining it just to connect it to the present and future to demonstrate the trends of development in events to direct then properly .Thus , history aims to collect information about the past and record and explain them to state the casual and collective reasons between them .Moreover, it sheds light on what is going in the present out of relations problems and behaviors to interpret the development which resulted on nations.(Abu Sarhan ,2000:16) 


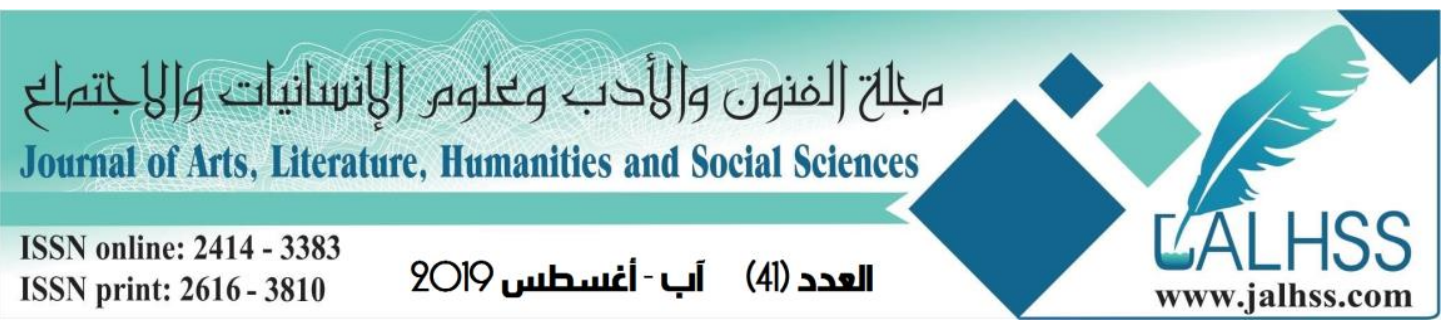

For this reason reading history is no longer considered as a source of entertainment by all its events, relations and stories, but it is on outstanding account of experience which has many functions that help build humans mentally and spiritually to achieve acceptable level of empowerment.

In order to achieve all that, it must be a suitable study subject matter for students taught in any educational grade(Al-Laqani and Auda , 1990:21). Accordingly, ministry of education should re-consider its aims, programmes systems and methods and it should diagnose the aspects and develop them according to scientific rules and maxims (Attiya , 2010:247)

Ministry of education attempts to raise productive and educated individuals that are motivated by active participation to serve their community and citizens .Besides, it tries to develop individuals' personalities together with motives, abilities, ideas , skills, values and trends. Moreover, it seeks to raise good citizens that act in a benefit of their community(Robi , 2002:25)

Since teaching according to limited programmes can facilitate the process of learning and enable teachers to achieve the aims of lessons and help students to develop and promote their mental abilities as well as their social interaction (Al-Afon \& Hussein, $2012: 207)$

On that basis, the researcher believes it is necessary to take a great care of new methods and strategies that are concerned with activating the role of students in the process of learning .Furthermore, she states that the availability of suitable study atmosphere can promote the abilities of the students and make them think and search. This will not be achievable unless there are innovative , open - minded and highly skilled teachers who can employ and invest these strategies to develop the educational process (Al-Farsaji and Musa, 2006:16) whose main occupation is to help students in all aspects including mental physical and psychological. So, these teachers are stimuli of learning, and directing an evaluating it (Al- Tantawi , 2009:167).This can be achieved through making any subject matter, especially, history an accurate, clear, connected and correlated and interesting. This can be fulfilled by using new and novel methods and strategies.(Attiya,2008:28)(Zaytoon,2001:189)

As a matter of fact, the success of the educational process rests on providing novel strategies that encourage active participation for students (e.g. reading, discussion, writing , ...etc.) This can develop these abilities , skills and motives (Charless, 1991: 12).

Students' participation is considered an important factor for learning to develop their independence in thinking through their active role in learning process (Barr and Tagg,1996:24).The teachers should encourage students to take his turn in answering and exchanging with their peers (Carla,2007:1)

Perhaps the main strategy that can achieve this aim is Tiered Activities Strategy in that each student starts his/her suitable activity for his/her skillful and cognitive level and gradually he /she can come to a very distinguished level(Kojak et al , 2008: 131132) 


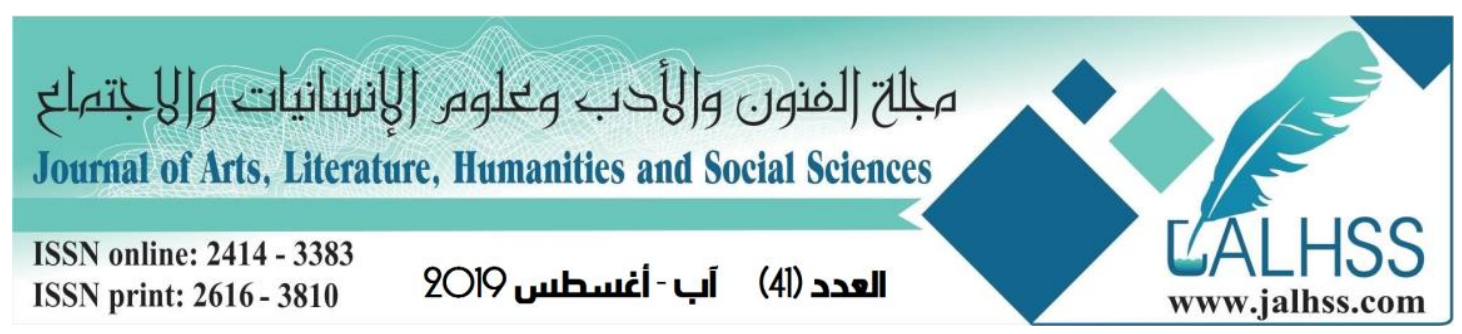

Results of paper and studies point out that it is necessary to include the cognitive motive among students in teaching and learning to ensure the success of teachers in motivating students to be very active in searching for knowledge. Consequently, the researcher defined the importance and significance of the study as the necessity of raising the level of achievement and the cognitive motive among fourth grade female students-literary stream in the history of the Arab Islamic civilization subject .Besides, this study is an attempt to deal with the impact of the Tiered Activities Strategy which is based on active learning and its strategies .Thus, the field of methods of teaching is in dire need to experimental studies that are concerned with using new models and strategies of teaching based on active learning that cope with modern trends and orientation.

\section{Aims of the Study}

The current research paper aims to identify the impact of tiered activities strategy upon achievement of history of the Arab Islamic civilization among fourth grade female students -literary stream.

\section{Limits of the Study}

The current research paper is limited to :

1. Fourth grade female students in Al-Bayan secondary school of girls subsidiary to the general directorate of Education .Al-Karkh Al-Awla

2. The second term of academic year 2017-2018

\section{Hypothesis}

To achieve the aims of the study, the following two null hypotheses have been formulated:

1.There is no statistical significant difference at significance level of $(0-05)$ between the average of female students scores of the experimental group who studied history of the Arab Islamic civilization subject according to the tiered activities strategy and the average of female students scores of the central group who studied the same subject according to the traditional method in achievement .

2. There is no statistical significant difference at significance level of $(0.05)$ between the average of female students scores of the experimental group who studied history of the Arab Islamic civilization subject according to the tiered activities strategy and the average of female students scores of the control group who studied the same subject according to the traditional method in the cognitive motive.

\section{Terms Definitions}

\section{Tiered Activities Strategy}

Kojak , Kuther Hussein et al , defined it as a method of teaching that is based on a type of educational activities that teachers design in the light of given aims and contents of curriculum. The teacher should take into consideration the diversity in types and levels to meet the students' needs ( Kojak, Kuther Hussein et al ,2008:135) 


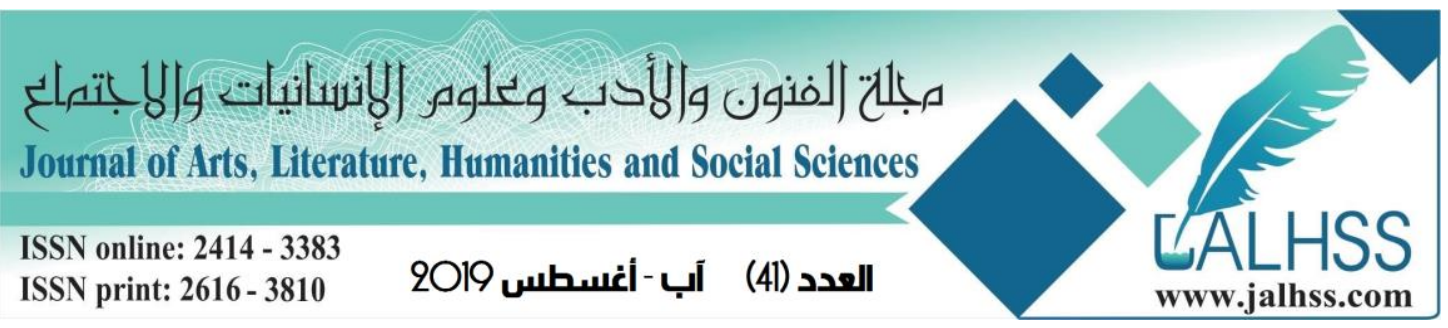

The researcher has adopted this definition as being a theoretical definition of this strategy which is used in teaching the experimental group.

\section{Achievement}

Al-Hamed (1996) defined achievement as " what individual learnt in school out of information during studying subjects and what individual perceived out of relations between information and what deduced out of facts reflected in his/her performance on a test according to rules that govern the learners' performance quantities" (AlHamed 1996:1)

The researcher defined achievement as what female student has got out of given experiences through her studying the contents of curriculum.

\section{The Operant Definition of Achievement}

Achievement is a bundle of information and experiences that female students got after they have been taught history of Arab Islamic civilization subjects and it can be measured by the scores that they got through the test results which the researcher has drawn up for this purpose.

\section{The Cognitive Motive}

Qatamy (1999) defined the cognitive motive as an internal state that stirred the learners' ideas and his /her cognitive construction as well as it directed his/her attention to continue performing to reach the cognitive balance (Qatamy,1999:171)

Abu Hatab and Amal (2013) defined the cognitive motive as the desire in knowledge, understanding and mastery of information as well as formulating problems with solutions (Abu Hatab and Amaal ,2013:450)

The researcher has defined the cognitive motive as the total score that female students got through their answers of the cognitive motive score used in this study.

\section{Theoretical Background \\ Firstly : Tiered Activities}

There is a great controversy whether tiered activities can be used in teaching or not .Thus, there are three different viewpoints : the first one called for ignoring these activities and focusing only on the given subjects.

The second viewpoint focused on conducting synchronous method associated with the teaching process . The third viewpoint is described as accepting these activities outside theframework of given methodology (Al-Hachamy , 2003:68)

It is not surprising that these activities are regarded as fields of selected expertise students get through and they lead to achieve educational aims, since students' participation in these activities will increase his/her learning (Al-Sharbeny and Sadeq ,2000:65) (Al-Teety,1993:50)

In fact ,these educational activities are deemed to be an integral part of building balanced personality of students. The main aim of these activities is to allow students the opportunity to connect or associate between the theoretical knowledge and direct experiences as well as the practical reality, teamwork and drawing up field work for individuals (Fateem and Abu Al-Azayem , 1988:318) 


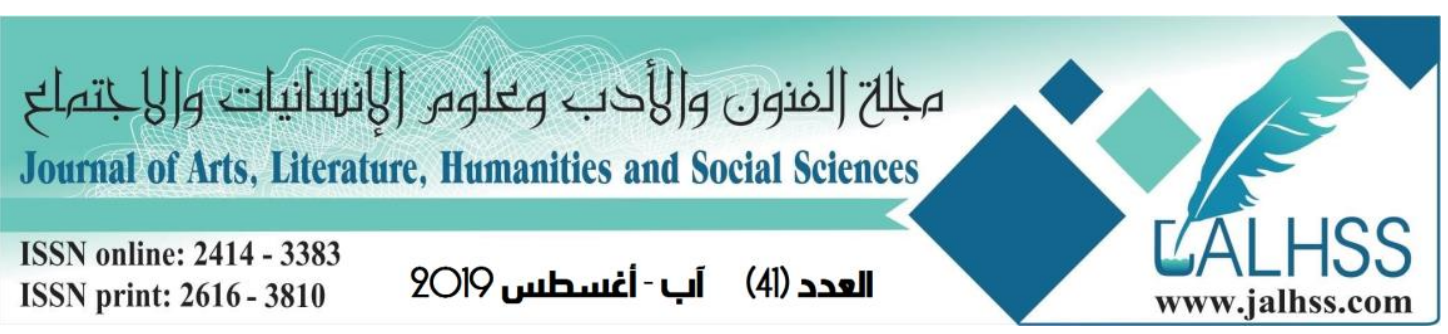

The students motivation on learning should be synchronous with using positive learning strategies which led to process accurate and deep information as well as a better academic performance (Rotgans, 2009:8)

The tiered activities can be based on levels of challenges complexity, resources, result or process or product (Heacox, 2002:10)

\section{The Tiered Activities Strategy}

The tiered activities strategy can be used when the cognitive and skillful levels of students differed .However, this difference in levels requires designing different and tiered activities in which each students begins performing his/her own suitable activity that fits into his/her own cognitive and skillful level .The tiered activities can be designed as follows:

1.Tiered activities in the level of challenge : for example, Bloom Taxonomy can be used to build different activities on the cognitive staircases in this taxonomy.

2. Tiered activities in the level of complexity that require difference in the extent of work progress and not a difference on the required quantity .

Group (A) low level of complexity which is regarded as a wall notice board that exhibit certain issue of given subject.

Group (B) high level of complexity which is regarded as a wall notice board that exhibit different viewpoints regarding certain subject .

Group ( C) high level of complexity which is regarded as a wall notice board that exhibit different viewpoints concerning certain subject.

3. Tiered activities according to available sources such as when group (1) used one source to read certain subject in the textbook (curriculum) and group (2) is required to compile what is written about certain subject in more than one book, a group (3) is required to do a research paper on the internet.

4. Tiered activities in the processes that must be done : for example, in these groups, it is required to conduct a research paper to reach the standards that must be taken into consideration when using a certain methods of teaching. One group does a reading research to extract the most important standards and the second group does a field research paper and holds interviews with a sample of teachers to survey their viewpoints about what they do care when they use certain method in teaching (Kojak, Kuther Hussein et al ,2008:131132)

Smith and Thrones (2007:55) suggested that the teacher should consider the following points when he /she used tiered activities strategy

1. Define a level of content subjects

2. Define learning outputs that teachers decided to achieve among students.

3. Define levels of students bearing in mind their interests and learning patterns.

4. Select feedback for each level and present suitable opportunities to comprehend what they learn . 


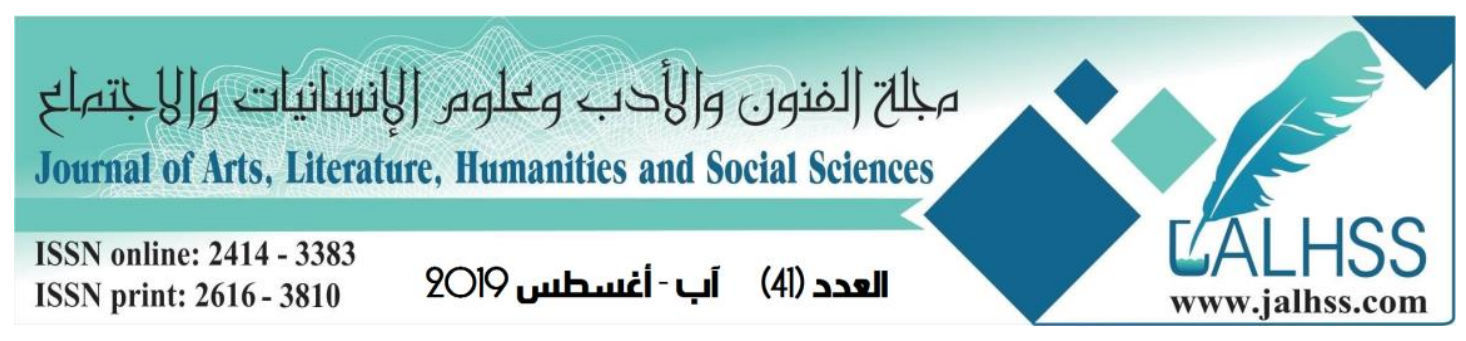

5. Think different levels of suitable activities according to students' abilities in each group.

6. Use suitable educational means to reinforce satisfied activities for students' needs .

\section{Secondly, The cognitive motive}

The cognitive motive is considered one of human motives which is developed at the hands of Gestalt psychologists. However, Cohen, Stooalnd and Wolfe have conducted studies through which they define the cognitive motive as human need to build suitable situations and meaningless attitudes, it is a must to understand the external world which is rife with experiences, in case of this prerequisite became exposed to frustration, feelings of tension and deprevation will arise which led to exert many efforts to build situations (Abu Hattab and Amaal ,1980:354)

Similarly , Cacioppo and Petty (1986) state that there are individual differences regarding individuals' tendencies towards preoccupation and enjoyment in the cognitive motive . They hold that individuals with high cognitive motive tend to stimuli or problems that require deep thinking (Abdullah,2004:147).Furthermore , individuals with high cognitive motive are internally motivated for deep thinking in complex issues ( Nelson ,2002:8)

\section{Aspects that Imply Cognitive Motive}

There are a bundle of aspects that imply cognitive motive .They are as follows:

1. Exploratory behaviour 2. Inquiry (Al-Kenany and Ahmed, 1995:202)

3.Curiosity knowledge

4. Quest for knowledge

5. Acceptance of challenges for the sake of attaining knowledge (Saleh , 2012:71)

\section{Mazen's Study -1986}

This study has been conducted with the aim of developing the method of teaching chemistry in the general secondary school by using reading specialized books of one subject .The sample consists of (74) students -Suhaj secondary school-Egypt-the sample is distributed randomly on two groups by (37) students for each group.

The experimental group studies the educational activities and the control group studies the same subject by the traditional method. The researcher has a questionnaire consisting of (19) questions distributed on (24) branches related to the educational activities .Each question is supplied by a list of different answers to allow students to express his /her opinion easily. Results showed that :

$1.83 \%$ of the sample stated that these activities achieved aims including students' need satisfaction, conduct practices new skills acquisition

2. Using experimental activities is successful as a scientific activity in acquiring these designed activities.(Mazen ,1986:238:263)

Saleh's Study (2012)

This study has been conducted in Iraq .The aim of this study is to identify the impact of strategies of information processing and rational inquiry in achieving Biology and 


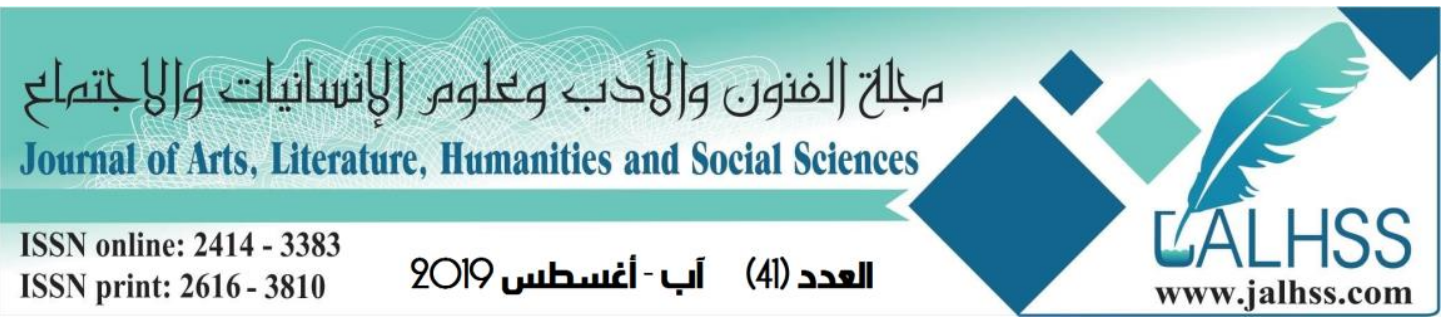

developing the scientific thinking and the cognitive motive. The researcher adopted the experimental degree of partial control of equivalent groups (experimental and control groups) of pre- and post-tests. The example consists of (120) students distributed on three equal groups (two experimental groups and one control group).The control group is taught by the traditional method and it depends on the strategy of information processing in teaching the first experimental group and the rational enquiry in teaching the second experimental group.

The researcher has prepared an achievement test in subject of Biology consisting of (50) item and validity and reliability has been verified .The scientific thinking test consists of (25) items distributed on five fields including (defining problem, choosing hypotheses , choosing the validity of hypotheses, explanation and generalization).Moreover, the researcher has prepared a scale of the cognitive motive consisting of (44) items distributed on four fields including (quest for knowledgecuriosity -exploratory and acceptance of challenges).

The researcher has used statistical package for social sciences (SPSS) to process data. Results show that the first and the second experimental groups surpassed (excelled) in achievement test.

The second experimental group has excelled in developing the scientific thinking while the first experimental group has excelled in developing cognitive motive (Saleh ,2012:16-142)

\section{Farajallah's Study (2012)}

The study has been conducted in Iraq with the aim of identifying the efficiency of Beyer strategy in achieving chemistry and developing the critical thinking and the cognitive thinking among second grade intermediate school students.

The researcher has adopted the experimental design of partial control for the two equivalent groups (experimental and control ) of pre and post test .The sample consists of (60) students distributed on two groups by (30) students in each group.

To achieve the objectives of the study, the researcher has conducted an achievement test consisting of (40) items and validity and reliability have been verified The critical thinking test consists of (60) items including five fields . The cognitive motive scale has consisted of (36) items including three fields namely quest for knowledge and desire for reading and curiosity and exploratory and raising questions. Data has been processed by using SPSS. Results show that the students of the experimental group have excelled in the variables of achievement, the critical thinking and the cognitive (Farajallah , 2012:15-134)

Some of the indicators from literature reviews:

Mazen's study (1986) has correspond with the current research paper in using activities as experimental variable as well as there is a conformity in the methodology of the paper to reach into results whereas Saleh's study (2012) have correspond with the variables of the cognitive motive .Consequently, previous literature reviews have used the experimental methodology to reach results after testing hypotheses. For this 


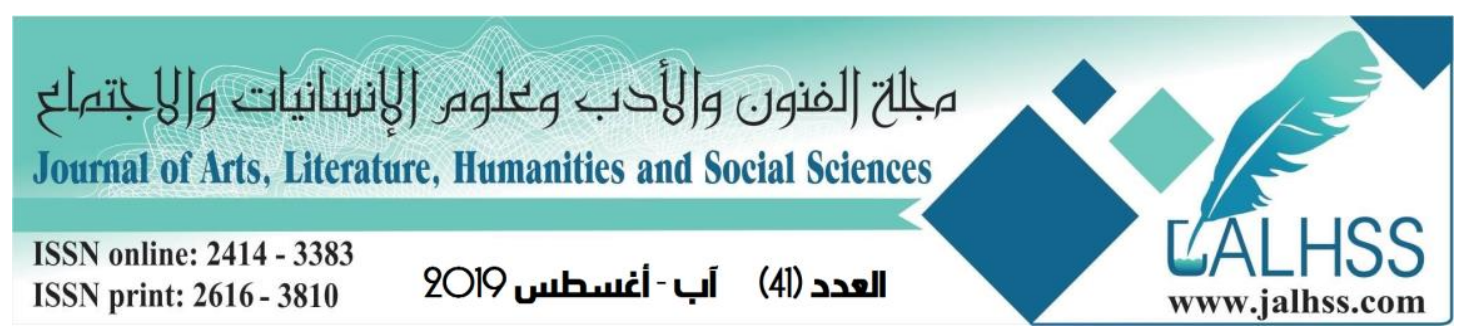

reason, the researcher has benefited from these hypotheses and she realized it is necessary to explore and search for the tiered activities strategy because of the scarcity of papers and students regarding this strategy.

\section{Methodology and Procedures}

Research Methodology

The research methodology represents the operant method to reach new truth that enables the researcher to overcome ambiguous problem and he /she can determine the nature of research together with its aims. The used methodology includes all processes, tools and procedures used in collecting required information and them analyzing it to get suitable answers to solve the problem (Hamdan ,1981:52)

The researcher selects the experimental method to test and examine its hypotheses for being the suitable method to control variables.(Mullhem ,2000:359)

\section{The Experimental Design}

Selecting the experimental design is regarded as a key process for every researcher to be able to reach wished results (Best , 1970:150). The experimental design is the skeleton or the general framework of the experiment for the sake of testing hypotheses (Mayers, 1990:104).To achieve this, the researcher has selected the experimental design of partial control and post-test as being the suitable on to achieve the aims of this paper, as shown in the following table :

\begin{tabular}{|l|l|l|l|}
\hline $\begin{array}{l}\text { The Two Groups of the } \\
\text { Paper }\end{array}$ & $\begin{array}{l}\text { The Independent } \\
\text { Variables }\end{array}$ & \multicolumn{1}{|c|}{ Post Tense } & The dependent Variable \\
\hline Experimental & $\begin{array}{l}\text { Tiered Activities } \\
\text { Strategy }\end{array}$ & $\begin{array}{l}\text { Achievement Test } \\
\text { And scale of } \\
\text { cognitive motive }\end{array}$ & $\begin{array}{l}\text { Achievement } \\
\text { The cognitive } \\
\text { Motive }\end{array}$ \\
\hline Control & $\begin{array}{l}\text { The Traditional } \\
\text { Method }\end{array}$ & \begin{tabular}{l} 
Mege \\
\hline
\end{tabular}
\end{tabular}

According to this design the two groups of the researcher paper are exposed to post test, to measure the achievement and the cognitive motive after the experimental group had been taught according to the tiered activities strategy and the control group according to the traditional method.

\section{Population}

The research population consists of fourth -grade female students in Al-Bayan Secondary school subsidiary to the directorate of Al-Karkh Al-Awla education.

\section{Research Samples}

The researcher has selected two sections randomly out of three sections $(\mathrm{A}, \mathrm{B}, \mathrm{C})$ of the fifth grade-literary stream .The researcher has selected two sections $(A, B)$ to be the current research sample. Section (A) represents the experimental group that is taught the history of the Arab Islamic civilization subject according to the tiered activities strategy. Section (B) represents the control group which is taught the same subject according to the traditional method. The number of students, in the two group 


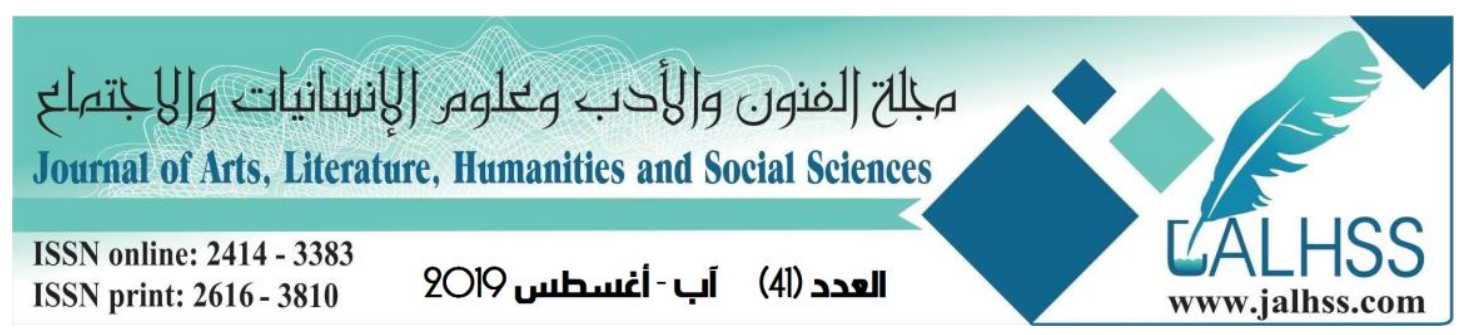

, has amounted to (60) students by (30) students in each group and after excluding (5) female students out of the experimental group and (4) female students out of the control group.

\section{Equivalence of the Two Groups}

The researcher has carried out the statistical equivalence between the two groups in the following variables :

\section{Age by Months}

Required information has been collected concerning the ages of female students through their experimental group female students has amounted to (195:81) months whereas the Arithmetical mean for the control group has amounted to ((194:86) months .The researcher has used T-test for two independent samples to calculate (measure) the significant differences between the mean of the ages of the two groups .The calculated T-value has amounted to (0-29) which is smaller than the tabulated (2) value at significance level of (0.05) with freedom degree of about (58) and table (1) below illustrates this fact :

Table (1) Equivalence of the two Groups in Age by Months

\begin{tabular}{|c|c|c|c|c|c|c|c|}
\hline Group & Sample & $\begin{array}{c}\text { Arithmetic } \\
\text { Mean }\end{array}$ & $\begin{array}{c}\text { Varianc } \\
\mathrm{e}\end{array}$ & $\begin{array}{c}\text { Freedom } \\
\text { Degree }\end{array}$ & Calculated & Tabulated & $\begin{array}{c}\text { Level of } \\
\text { Significance } \\
0.05\end{array}$ \\
\hline Experimental & 30 & 195.81 & $16-91$ & & & & T-Value \\
Control & 30 & 194.86 & $38-44$ & 58 & 0.29 & 2 & $\begin{array}{c}\text { Not } \\
\text { significance }\end{array}$ \\
\hline
\end{tabular}

\section{History Achievement in mid-term Exam}

The ranks of the two groups have been obtained out of the school records. The arithmetic mean has been calculated which has been amounted to (07.88) for the experimental group whereas (65.03) for the control group. The researcher has used Ttest for two independent samples to calculate the significance differences between the two averages of the marks of the two groups. It appeared that the calculated T-value is (0.203) which is smaller than tabulated T-value which is (2) at significance level of about (0.05) with freedom degree of about (58). Table (2) illustrates this fact:

Table (2) Equivalence of the two Groups in Achieving History subject in mid term Exam

\begin{tabular}{|c|c|c|c|c|c|c|c|}
\hline Group & Sample & Arithmetic & Variance & Freedom & \multicolumn{2}{|c|}{ T-Values } & Level of \\
\hline Experi & 30 & $67-88$ & 280 & \multirow[b]{2}{*}{$J$} & Calculated & Tabulated & \multirow{2}{*}{$\begin{array}{c}\text { Not } \\
\text { significance }\end{array}$} \\
\hline Control & 30 & 65.03 & 150,66 & & 0.204 & 2 & \\
\hline
\end{tabular}




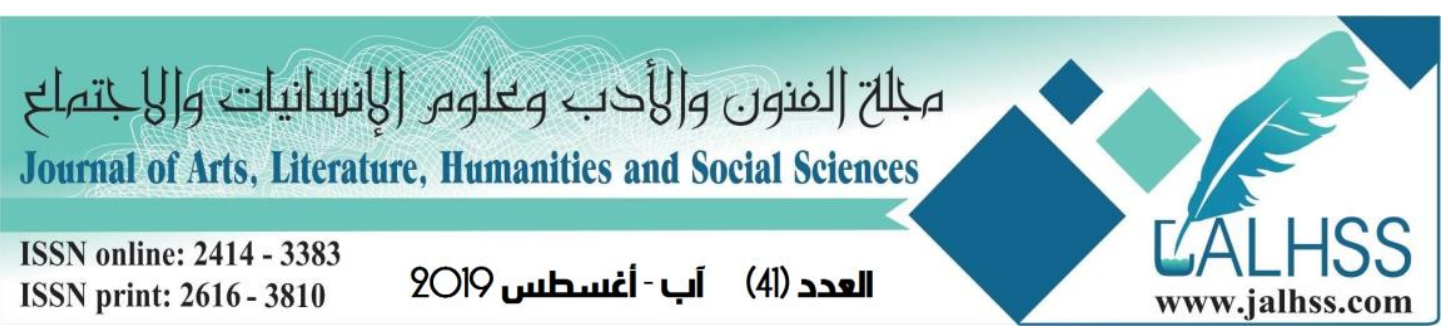

Table (3) Parents' Academic Achievement

\begin{tabular}{|l|c|c|c|c|c|c|}
\hline Rank Status & 1 & 2 & 3 & 4 & 5 & 6 \\
\hline $\begin{array}{l}\text { Parents' } \\
\text { Academic } \\
\text { Achievement }\end{array}$ & illiterate & $\begin{array}{c}\text { Primary } \\
\text { school }\end{array}$ & $\begin{array}{c}\text { Intermediate } \\
\text { school }\end{array}$ & $\begin{array}{c}\text { Secondary } \\
\text { school }\end{array}$ & $\begin{array}{c}\text { Institute } \\
\text { college }\end{array}$ & $\begin{array}{c}\text { Post- } \\
\text { graduate } \\
\text { Education }\end{array}$ \\
\hline & Zero & 1 & 2 & 3 & 4 & 5 \\
\hline
\end{tabular}

According to the above table, the parents' academic achievement scores have been collected for each students which range from (zero-10). To verify the equivalence of the two groups in the levels of parents' educational achievement, the arithmetic mean has been calculated and amounted to (7.77) of the experimental group and (7.3) for the control group. The researcher has used T-test for the two independent samples to measure the significance differences between the two averages .It appeared that the calculated T-value has amounted to (0.015) which is smaller than tabulated which amounted to (2) at level of significance of about (0.05) with freedom degree of about (58) .Table (4) illustrates this

Table (4) Equivalence of the Two Groups in the Level of Educational Achievement of Parents

\begin{tabular}{|c|c|c|c|c|c|c|c|}
\hline \multirow[t]{2}{*}{ Group } & \multirow{2}{*}{$\begin{array}{l}\text { Sampl } \\
\text { e }\end{array}$} & \multirow{2}{*}{$\begin{array}{l}\text { Arithmet } \\
\text { ic } \\
\text { Mean }\end{array}$} & \multirow{2}{*}{$\begin{array}{l}\text { Varianc } \\
\text { e }\end{array}$} & \multirow{2}{*}{$\begin{array}{l}\text { Freedo } \\
\mathrm{m} \\
\text { Degree }\end{array}$} & \multicolumn{2}{|c|}{ T-Values } & \multirow{2}{*}{$\begin{array}{l}\text { Level of } \\
\text { Significan } \\
\text { ce } \\
0.05\end{array}$} \\
\hline & & & & & $\begin{array}{c}\text { Calculat } \\
\text { ed }\end{array}$ & $\begin{array}{c}\text { Tabulate } \\
\text { d }\end{array}$ & \\
\hline $\begin{array}{l}\text { Experiment } \\
\text { al }\end{array}$ & 30 & 67.88 & 260 & \multirow[t]{2}{*}{58} & \multirow[t]{2}{*}{0.204} & \multirow[t]{2}{*}{2} & \multirow{2}{*}{$\begin{array}{l}\text { Not } \\
\text { significano } \\
\mathrm{e}\end{array}$} \\
\hline Control & 30 & 65.03 & 150.66 & & & & \\
\hline
\end{tabular}

\section{Research Paper Requirements and Sources of Information Determining Educational Subject Matters}

The researcher has limited the scientific subject matter which will be taught for the two groups, experimental and control, according to the subjects of each chapter which will be given in the second term of the year in the book of history of the Arab Islamic civilization textbook designed for the fourth -grade students -literary stream .Republic of Iraq for the scholastic year (2017-2018). The subjects are as follows :

Chapter Five : The Military Institution

Section (1) The Army

Section (2) The Navy

Chapter Six : Population life in countryside and cities

Section (1): Agriculture

Section (2): Arab and Islamic cities and countries

Chapter Seven : The Intellectual Movement 


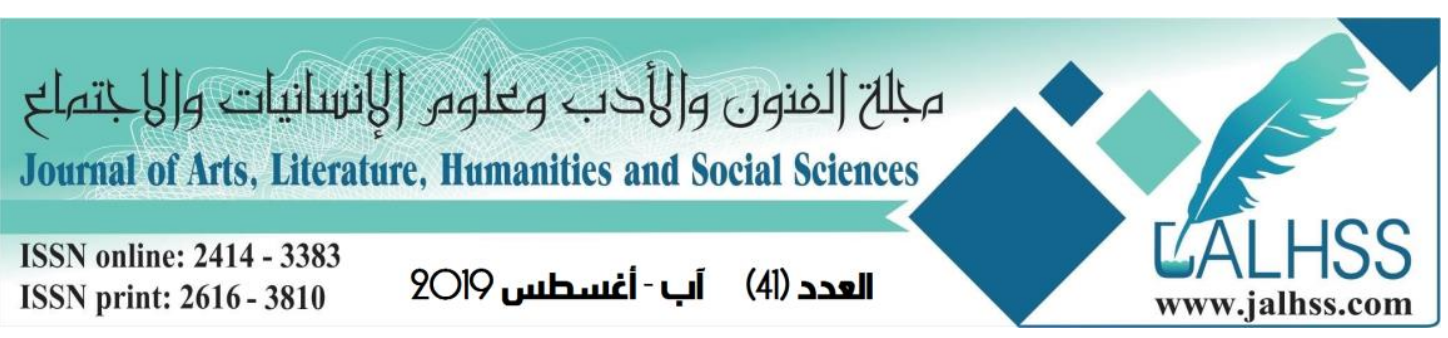

Section (1) Factors of Flourishing the intellectual movement

Section (2) Factors of the intellectual movement

Section (3) Centers of the intellectual movement

\section{Drawing up the Teaching Plans and Behavioral Aims (Objectives)}

The researcher has drawn up teaching plans for the two groups depending on the contents of the behavioral aims : (24) teaching plans have been drawn up and behavioral purposes have been formulated according to Bloom's taxonomy in the cognitive field (knowledge, understanding, application and analysis ).(90) behavioral purposes have been formulated and they have been reviewed by a number of reviewers (specialized in methods of teaching social and educational sciences and they approved them in $(90 \%)$, the researcher has carried out some modifications that have been suggested by reviewers in altering some of the plans and formulation of a number of behavioral purposes.

\section{The Two Instruments of the Research Paper}

The First Instrument : The Achievement Test

The researcher has designed an achievement test in the light of the contents of the subject matters that have been supposed to be taught during the period of experience of the behavioral purposes of the experience has undergone several stages . They are as follows:

\section{Preparing the Experimental Map}

The researcher limited the relative importance of the behavioral purposes through distributing a questionnaire on a number of female teachers (headmistresses) in their capacity as having high experience in the educational subject matter to determine the relative importance of behavioral purposes .The following rates have been delimited, (30\%) for knowledge ,(25\%) for comprehension , (35\%) for application and (10\%) for analysis .The total number of items of achievement test became (60) items .Table (5) illustrates this fact:

Table (5) Shows the Experimental Map for the items of achievement Test

\begin{tabular}{|c|c|c|c|c|c|c|}
\hline Content & $\begin{array}{c}\text { The } \\
\text { Relative } \\
\text { Importance } \\
\text { of } \\
\text { Contents }\end{array}$ & $\begin{array}{c}\text { Knowledge } \\
30 \%\end{array}$ & $\begin{array}{c}\text { Comprehension } \\
25 \%\end{array}$ & $\begin{array}{c}\text { Application } \\
35 \%\end{array}$ & $\begin{array}{c}\text { Analysis } \\
10 \%\end{array}$ & $\begin{array}{c}\text { No. } \\
\text { of } \\
\text { Items }\end{array}$ \\
\hline $\begin{array}{c}\text { Chapter } \\
5\end{array}$ & $35 \%$ & 6 & 5 & 8 & 2 & 21 \\
\hline Ch.6 & $30 \%$ & 5 & 4 & 7 & 2 & 18 \\
\hline Ch.7 & $35 \%$ & 6 & 5 & 8 & 2 & 21 \\
\hline Total & $100 \%$ & 17 & 14 & 23 & 6 & 60 \\
\hline
\end{tabular}




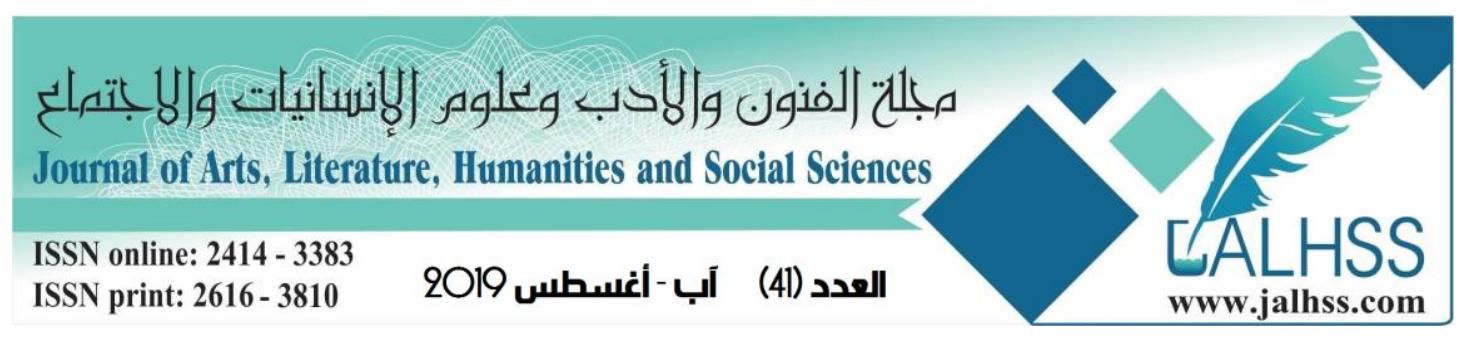

\section{Formulating Test Items}

The current test includes two types of tests : objective tests and essay tests. The objective tests consist of (50) items and the essay items consist of (10) items .The question items are distributed according to the behavioral purposes with above mentioned four levels .

\section{Test Validity}

To verify the test validity, the researcher has put forward the test in its primary formulation amounting to (60) items on a group of reviewers (referees) specialized in methods of teaching social sciences. For the purpose of verifying test validity in terms of the scientific accuracy, formulation, and consistency of the behavioral purposes with the test items as well as the approval of reviewers regarding the comprehensiveness of the test of the content together with its clarity of its items and the extent of measuring the levels of given behavioral purposes as well as distributing marks on the items and the logical aspect of alternatives. In the light of their opinions , sometimes have been modified to reach to the face validity.

\section{Instructions of Correcting Achievement Test}

The researcher has prepared typical answers for test items to correct answers. Each item of the objective test has given one mark if the answer is correct and zero if it is wrong or left .Thus, th total marks of items range is from (0-50). As to the essay questions the range is from (zero -2) mark for each question.Thus, the total marks are ranging from (zero -20). Accordingly, the total marks of the test are (70) marks .

\section{Pilot Experiment}

After verifying the face validity, validity of content as well as the psychometric characteristics, coefficient of reliability, elapsed time estimation in answering. The researcher has applied a pilot sample amounting to (100) female students who have been chosen from fourth-grade .Al-Furat secondary school for girls general education Directorate of Al-Karkh Al-Awla .The researcher has checked the validity of items .The time has come to (50) minutes.

\section{The Statistical Analysis of Test Items}

The key aim of the statistical analysis of test items is to identify the level of difficulty of each item and its ability to differentiate among outstanding and retarded students and the other important aim is to identify the proficiency of wrong alternative or options of these items and then evaluating or judging the range of validity of building and reliability of the test. Thus, the researcher has conducted the statistical analysis of test items to identify the main psychometric characteristic after being applied on the pilot sample in the following manner:

\section{Item Difficulty Level}

Item difficulty level is calculated via the percentage of correct answers on that item .If this ratio is high, this means that the item is very easy and if this ratio is low , this means that the item is very difficult .The item difficulty level has been calculated and it is found that the level falls between $(0.60-0.78)$ and these values are acceptable 


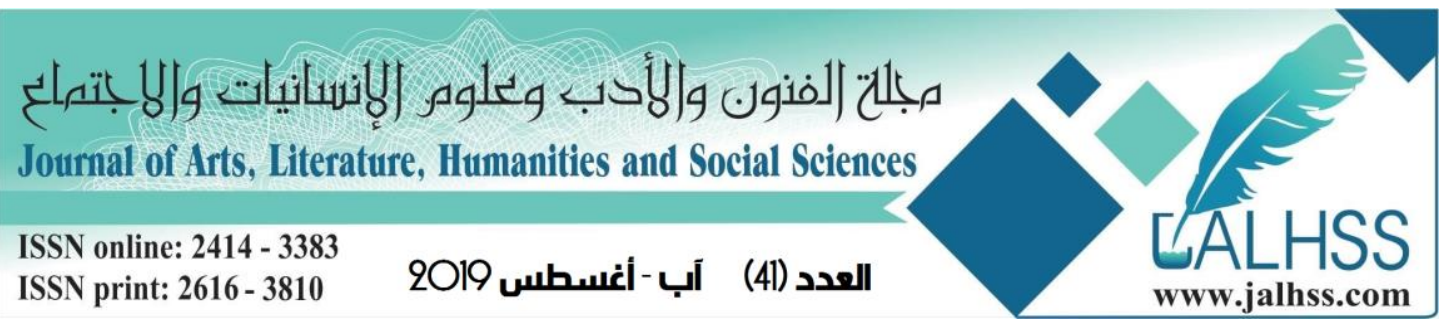

.Thus, Bloom (1971)found that if the items range between $(0.20-0.80)$.This means that they are accepted.

\section{Item Discrimination Index}

Test items are considered as having positive discrimination if the number of answers of the high individual group are more than the low individual group. Thus, after arranging the scores obtained by the female students of the pilot sample from which high and low groups have been taken by ratio of (27\%) out of the number of pilot sample .Then, the discrimination force of items have been calculated which range from (0.41-0.68) .Brown (1981) found that the test item has discrimination force of about (0.20) is regarded as a good item .

\section{Wrong Alternatives Activity}

It is found that the wrong alternatives of low group are more than the wrong alternatives of high group. Thus, after calculating the activity of each wrong alternative and each test item, it is found that the wrong alternatives have attracted a large number of low group individuals as compared with high group individuals .Accordingly, it has been decided to maintain the wrong alternatives as they are without any change .

\section{Test Reliability}

The test reliability is considered as an index of the internal consistency of test. Thus, Kuder- Richardson 20 Formula is a measure reliability for a test with binary variables. Reliability refers to how consistent the results from the test are, or how well the test is actually measuring what you want it to measure. The coefficient of reliability has amounted to (678) which is regarded as acceptable for non-standard test if the reliability coefficient range from (0.60 -0.85)which is regarded acceptable .

\section{Secondly :Cognitive Motivation Scale}

After reviewing a number of scales relating to cognitive motivation ,the researcher found that the best scale was Al-Hussainy (2015)below is a brief summary of the scale :The scale consists of five fields : they are as follows :

1.Quest for knowledge 2.Cruiosity 3.Discovery and exploration 4.Aceptance of challenges

\section{Raising questions}

The number of items has amounted to (50) items distributed into five fields, each field consists of (10) items - ranging from (41) positive items to (9) negative items. Likert five point scale is used in preparing the scale items because it is used to allow the individuals to express how much they agree or disagree with a particular statement .There are five alternatives of answering each item .They are as follows: (it applies to me to very high degree, it applies to me to high degree, it applies to me to medium degree, it applies to me to a low degree, it does not apply to me) .

The $(1,2,3,4,5)$ marks have been given successfully for positive items and $(5,4,3,2,1)$ marks have been given for negative items. Thus, the high degree has amounted to (150) and accordingly, Al- Hussainy has checked the psychometric characteristics of 


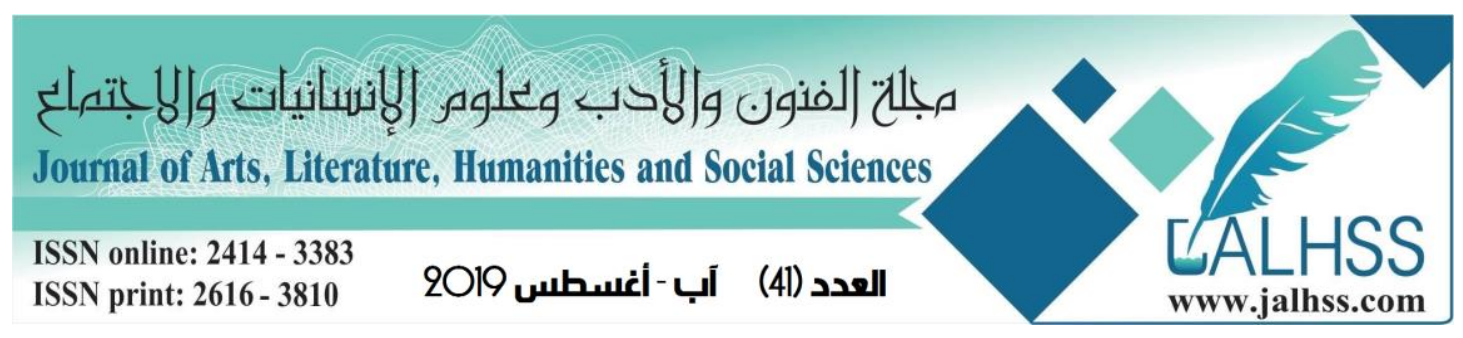

the scale in terms of validity and reliability, and calculating item discrimination force and its internal consistency (Al-Hussainy ,2015;130-139)

Procedures of the Experimental Design Safety

The researcher has verified the internal and external safety of the experimental /design through controlling its effects as follows:

\section{(A) The Internal Safety}

The internal safety aims at identifying and processing the following factors:

1.There is no pre - test for the experimental design of the research paper

2.The two instruments of one scale for the two groups represented by academic achievement test and the cognitive motivation scale

3. The two experimental and control groups are considered statistically equivalent as well as the individuals are consistent.

4. The two groups have been taught in one school .

5.Transfer between the two groups are not permitted during period of experiment

6.Pre-planned experiment and method of planning avoids accompanying accidents.

(B) The External Safety aims to identify and process the following factors:

1. Avoiding the effect of experimental procedures by teaching the two experimental and control groups .

2. Avoiding the effect of multiplicity in the experimental variables in each group by expressing each group to one method of teaching .

3. The method of teaching has been selected randomly.

4. There is no bias in selecting the research sample because it represents the community of the fourth grades in school.

5.The researcher has taken up correcting and checking students answers on the academic achievement test and the scale of cognitive motivation and the researcher has observed the scores of each group to be processed statistically.

Applying the Academic Achievement Test and the Cognitive Motivation Test

The researcher has prepared copies of test with answer sheets and two headmistresses have supported the researcher in carrying out the test application.

\section{The Statistical Means}

The researcher has used the following statistical means :

1. T-test, Pearson correlation coefficient, item difficulty coefficient formula, item discrimination coefficient ,Alpha Cronbach , Kuder-Richardson formula (Al-Amam et al , 1996:115)

Interpretation and Display Results

In the light of the statistical processing of resulting data of applying the two instruments of the research paper, the results can be displayed and interpreted according to the two hypotheses of the research paper as follows :

\section{The First Hypothesis}

There is no statistical significant difference among the average of grades female students of experimental group who studied the Islamic Arab civilization history 


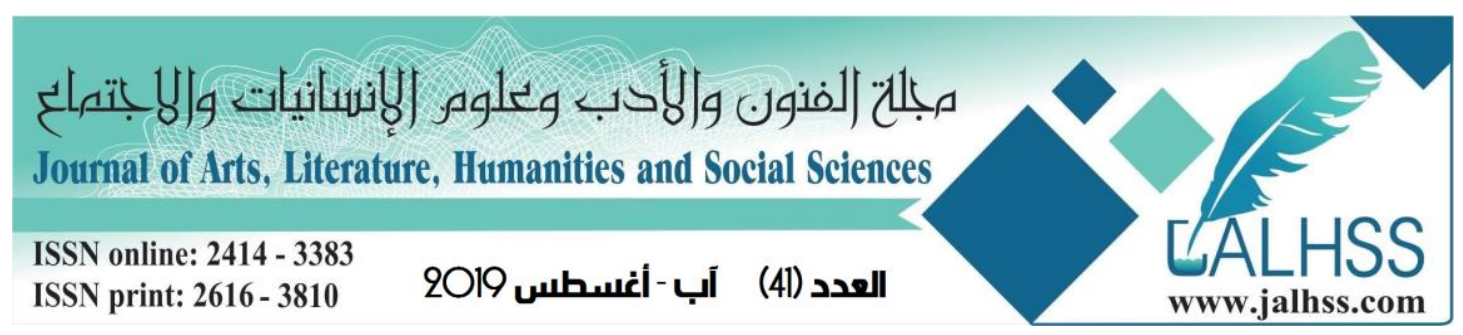

according to the tiered activity strategy and the average of the grades of female students of control group who studied the same subject by traditional method.

Through comparing the results of the academic achievement test of the two groups, it appeared that the average of the grades of the experimental group has amounted to (46.34) and the average of the grades of the control group has amounted to (37.84) by using T-test for two independent samples to identify the significant difference between the two averages and thus it is found that there is a statistical significant difference between the two groups for the benefit of the students of the experimental group .Accordingly, the null hypothesis has been rejected and table (6) illustrates this fact .

\section{Table (6) shows the results of T-test of the two groups of the research paper in} the academic achievement test .

\begin{tabular}{|l|c|l|c|c|c|c|c|}
\hline \multicolumn{1}{|c|}{ Group } & Number & $\begin{array}{l}\text { Arithmetic } \\
\text { Mean }\end{array}$ & Variance & \multicolumn{2}{|c|}{ T-Value } & Freedom & $\begin{array}{l}\text { Level } \\
\text { of } \\
\text { Significance } \\
\text { Degree }\end{array}$ \\
\cline { 1 - 3 } & & & & Calculated & Tabulated & significant \\
\hline Experimental & 30 & 46.34 & 53.93 & 4.30 & 2 & 58 & \\
\hline
\end{tabular}

Table (6) shows that the calculated T-value amounting to (4.30) is greater than the tabulated T-value amounting to (2) with freedom degree of about (58) at significance level of about (0.05). This means that there is a statistical significance difference in favour of the female students of the experimental group. Accordingly ,the null hypothesis has been rejected. As a result, the traditional method of teaching has not achieved the educational objectives reinforces the students' needs and encourages students to acquire new data and information.

\section{The Second Hypothesis}

There is statistical significance difference among the average of the female students of the experimental group who studied history of Islamic Arabic civilization according to the tiered activity and the average of female students of the control group who studied the same subject according to the traditional method.

Through comparing the results of the cognitive motivation scale of the two groups .It appeared that the average of the grades of the experimental group amounted to (193.32) whereas the average of the grades of the control group amounted to (170.21) and by using T-test for the two independent samples to identify the difference between the two averages .It is found that there is a statistical significant difference between the two groups in favour of the experimental group students.Accordingly, the null hypothesis has been rejected .Table (7) shows that fact: 


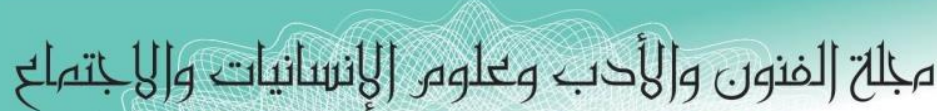

Journal of Arts, Literature, Humanities and Social Sciences

ISSN online: 2414 - 3383

ISSN print: 2616 - 3810
LALHSS

www.jalhss.com

Table (7) shows the results of the T-test of the two groups in the cognitive motivation.

\begin{tabular}{|c|c|c|c|c|c|c|c|}
\hline \multirow[t]{2}{*}{ Group } & \multirow[t]{2}{*}{ Number } & \multirow{2}{*}{$\begin{array}{l}\text { Arithmetic } \\
\text { Mean }\end{array}$} & \multirow{2}{*}{$\begin{array}{l}\text { Standard } \\
\text { Deviation }\end{array}$} & \multicolumn{2}{|c|}{ T-Value } & \multirow{2}{*}{$\begin{array}{c}\text { Freedom } \\
\text { of } \\
\text { Degree }\end{array}$} & \multirow{2}{*}{$\begin{array}{l}\text { Level of } \\
\text { Significance }\end{array}$} \\
\hline & & & & Calculated & Tabulated & & \\
\hline Experimental & 30 & 193.32 & $60-81$ & \multirow[t]{2}{*}{4.30} & \multirow[t]{2}{*}{2} & \multirow[t]{2}{*}{58} & \multirow[t]{2}{*}{ significant } \\
\hline Control & 30 & 170.21 & $68-42$ & & & & \\
\hline
\end{tabular}

Table (7) shows that the calculated T-value amounting to (4.30) is greater than the tabulated T-value amounting to (2) with freedom degree of about (58) at level of significance of about (0.05), that means there is a statistical significant difference in favour of the experimental group .Accordingly, the second null hypothesis has been rejected. It is found that the teaching according to the tiered activity strategy led to improve the quality of learning process among motivation of the students as well as it enhanced the positive interaction among students.

\section{Conclusion}

In the light of the results of the research paper, the researcher has come up with the following concluding points:

1. Teaching, according to the tiered activity strategy, reinforces the level of academic achievement among female students through fair active participation in the educational process.

2. Teaching, according to the tiered activity strategy, enhances the cognitive motivation of female students through the availability of opportunities of selfexpression and variation of activities and this led female students to response positively to classroom stimuli.

\section{Recommendations}

In the light of the findings of the research paper, the researcher has recommended the following:

1. Using the tiered strategy in teaching history of Islamic Arabic civilization because it is so important in enhancing and reinforcing the levels of academic achievement and the cognitive motivation among the fourth -grade female students -literary stream .

2. Female students have the opportunity to participate in the active activities that encourage them to think in the given information inside classroom as well as they can develop their abilities in analysis and discussion.

\section{Suggestions for Further Reading}

1.Conducting a study to identify the impact of the tiered activity strategy in developing orientation towards history subject matter 


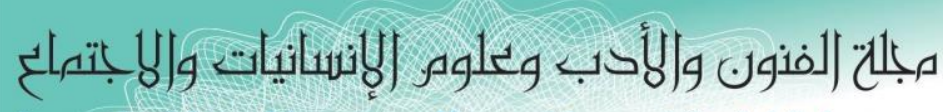

Journal of Arts, Literature, Humanities and Social Sciences

ISSN online: 2414 - 3383

ISSN print: 2616 - 3810

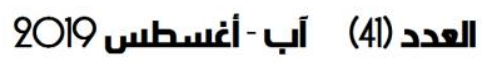

2. Conducting a study to let know about the study effect of the tiered activity strategy in acquiring the historical concepts.

3.Conducting a study to pinpoint the influence of the tiered activity strategy in developing the critical thinking.

\section{References}

1. Abu Hattab ,F.\& Sadiq A. (2013) Educational Psychology .ed.(2) AngloEgypt Library

2. Abu Sarhan, A. A. (2000) Studies in Methods of Teaching Social and National Education .ed.(1) Amman :Dar Al-Khalij of Publishing and Distribution

3. Al-Emam ,M.M. (1990) Evaluation and Measurement. Baghdad: Dar AlHikmah for Publishing and Distribution.

4. Al-Jamal ,A.A. (1999) The Effect of Using Educational Institutes in Teaching the Messenger's Islamic Conquests (PBUH) .Ain Shams University.

5. Al-Hamed , M.M. (1996) The Academic Acievement, Studies, Theories.

6. Al-Hachami,T.O. (2001) The Effect of the Behaviour of Primary School Pupils with the Raw Materials of Local Environment in Learning Stages of Discovery .Unpublished Master's Degree Thesis .College of Teachers .University of Mustinsirriya.

7. Al-Huseiny ,M.A.H. (2015) The Effectiveness of Educational Progrmme according to the Constructive Theory in Achieving Geography Subject Matter and the Cognitive Motivation among Fifth Grade Students Literary Stream .Doctoral Dissertation .College of Education /Ibn Rushd for Human Sciences.

8. Hamadan ,M. Z. (1989) The Scientific Research as a System .Amman :Dar Al- Tarbaya AlHadeetha

9. Khreesha ,A. K.(1997) The Effect of Gender and the Educational Level among Basic grade School in Jordan Concerning Temporal Concepts. Journal Studies ,issue (1) Vol.(24) Amman ,Jordan

10. Rabee ,H.M. (2008) The Contemporary Trends in Education ed.(1) .Amman: The Arab Scholarly Library .

11. Zaytoon ,H. H. (2001) Designing of Teaching (P erspective Vision) ed.(2) Cairo: World Books House

12. Al-Sharbiny ,Z.Y. \& Yousriya S. (2000) Development of the Scientific Concepts among Children . Cairo: Arab Thinking House

13. Al-Shawan A. (1999) The Extent of Intermediate School Students' Acquisition of Al- Riyadh City, the Historical and Geographical Concepts in textbooks ,the Educational Journal Vol.(13) issue (52) 


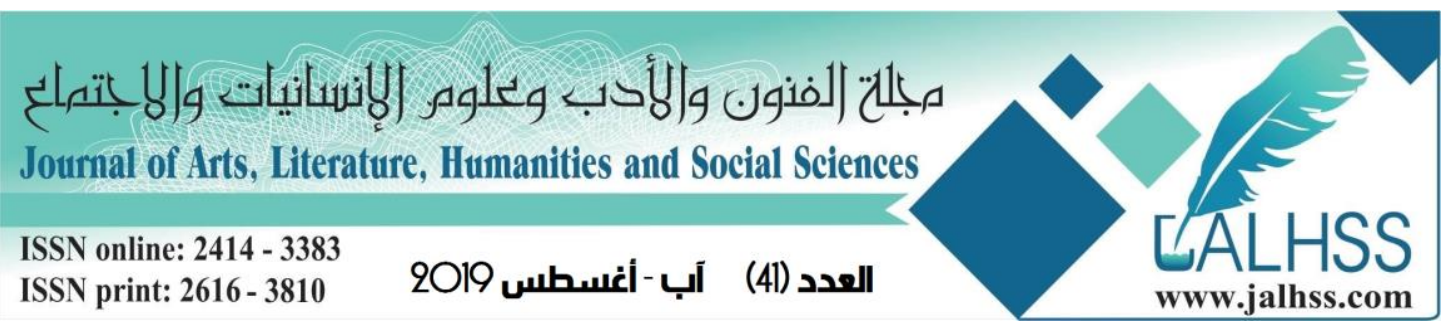

14. Saleh , H. Y. (2012) The Effect of Strategies of Information Processes and Rational Quest in Achieving Biology Subject Matter and Development, the Scientific Thinking and the Cognitive Motivation .

15. Al-Tannawi,A.M.(2009) Active Teaching -Planning -Skills -Strategies Assessment ed.(1) Amman :Dar Al-Maysara

16. Al-Teeti, M.H.A. (1993) Teaching Concepts ed.3 Amman : Dar Al-Amal

17. ----one Extent of Acquisition of Geographical Concepts among Teachers of Geography in Achieving these Concepts among Third Grade Students and the Skills in the Schools of International Relief Agency in Jordan .Unpublished Master degree Thesis .Al-Yarmouk University .

18. Abdulazeez , A.A.(1995) The Effect of Using the Cooperative Learning Strategy in Teaching History upon the Academic achievement, and Direction towards Studying History among First intermediate Students " The Seventh International Conference : The Intermediate Learning and Challenges of the Twenty First Century, Egyptian Association of Curriculum and Methods of Teaching .

19. Atiya ,M.A. (2008) Modern Strategies in Active Teaching .ed.(1) Amman : Dar Safaa

20. (2010) The Basics of Modern Education and Education Systems.Amman : Dar Al-Manahij

21. AL-Afoon , N.H. \& Hussein Salim Makawin (2012) Training Science Teacher According to the Constructive Theory ed.(1) Amman : Dar Safaa

22. Ghabari ,Th.A. (2008) The Theoretical Motivation and Application ed.(1)Amman : Dar Al-Masira

23. Al-Faraji, H.A. \& Mousa , A. A( 2006) The Activities and Educational Skills ed.(1) Amman : Dar Knooz

24. Farajallah ,H.T. (2012) The Effectiveness of Bayer Strategy in Achieving Chemistry Subject Matter and Developing Critical Thinking and Cognitive Motivation among Third Grade Students .Unpublished PhD Dissertation .College of Education /Ibn Al-Haitham.

25. Fateem ,L. \& Abu Al-Azayam ,A. (1988) Theories of Learning .Cairo : Al-Nahdha Library.

26. Qatami , N. (1999) School Psychology ed.(1) Amman : Dar Al-Sharooq.

27. Al-Kinani , M. 7 Al-Kindri , A.M. (1995) Psychology of Learning and Patterns of Learning. UAE :Al-Falah Library for publishing

28. Kojak , K. H (2008) Diversification of Teaching inside classroom as evidence used by Teachers to Improve Method of Teaching and Learning in Schools of the Home land .Beirut : UNISCO office of Education in The Homeland

29. Al-Fani, A.H. \& Oda ,A. (1990) Methods of Teaching Social Studies .Amman : Dar Al-Thaqafa for Publishing and Distribution 


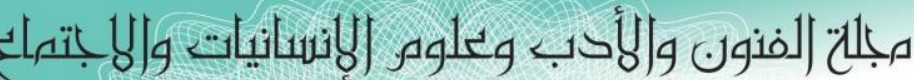

Journal of Arts, Literature, Humanities and Social Sciences

ISSN online: 2414 - 3383

ISSN print: 2616 - 3810

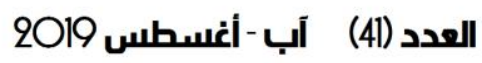

30. Mazen , H.M. (1986) The Effect of Using Some of Educational Activities in Achieving Some Objectives of Teaching Chemistry in Second Grade of Secondary School. Journal of Education ed.(1) Feb . College of Education in Sohaj, Asyoot University

31. Mayriz , A. (1990) The Experimental Psychology :Translated by Khalil Ibraheem Al-Bayti .Baghdad: Dar Al-Hikma for Publishing and Distribution

32. Al-Mikhlafi M.S. \& Al-Salimi ,H.(2001) The Extent of Acquisition among Third Grade School of Concepts included in the History Textbook in Oman. College of Education.University of Sultan Qaboos

33. Mulham ,S. (2000) Methods of Research in Education and Psychology .Amman :Dar Al-Maseer for Publishing and Distribution. 